Cahiers d'études africaines

$240 \mid 2020$

Soudan : identités en tension

\title{
Ali Nada Mustafa. - Gender, Race and Sudan's Exile Politics: Do We All Belong to this Country?
}

\section{Katarzyna Grabska}

\section{OpenEdition}

\section{Journals}

Electronic version

URL: https://journals.openedition.org/etudesafricaines/32843

DOI: 10.4000/etudesafricaines.32843

ISSN: $1777-5353$

\section{Publisher}

Éditions de l'EHESS

\section{Printed version}

Date of publication: 2 December 2020

Number of pages: 1015-1017

ISSN: 0008-0055

\section{Electronic reference}

Katarzyna Grabska, "Auı Nada Mustafa. - Gender, Race and Sudan's Exile Politics: Do We All Belong to this Country?", Cahiers d'études africaines [Online], 240 | 2020, Online since 02 December 2020, connection on 06 January 2023. URL: http://journals.openedition.org/etudesafricaines/32843 ; DOI: https:// doi.org/10.4000/etudesafricaines.32843

This text was automatically generated on 6 January 2023.

All rights reserved 


\title{
Ali Nada Mustafa. - Gender, Race and Sudan's Exile Politics: Do We All Belong to this Country?
}

\author{
Katarzyna Grabska
}

\section{REFERENCES}

Aur Nada Mustafa. - Gender, Race and Sudan's Exile Politics: Do We All Belong to this Country? London, Lexington Books, 2015, 215 p., index.

1 "Do we all belong to this country?" asks Nada Mustafa Ali in her book entitled: Gender, Race and Sudan's Exile Politics. The title of the book is taken from a speech given in 1998 in Cairo by anthropologist Sharif Harir, the vice president of the Sudan Federal Democratic Party and member of the Sudan's National Democratic Alliance's executive office at that time, in which he discussed structural racism in the Old Sudan. While the issues of racism, gender and belonging have been at the centre of Sudanese politics in the Old Sudan, they were also key in the debates in 1990s and 2000s about the visions of the New Sudan, a term coined by John Garang in 1983. Although much less discussed in the book, Nada Ali's research, however, is also relevant to issues of nation-building projects that both Sudans have faced since their separation in 2011. These concerns are even more relevant in the current situation in Sudan, with the regime change that took place in 2019 due to the civil protests initiated in December 2018. Who belongs and how in the post-revolutionary Sudan is at the heart of the current debates about citizenship and rights in the country.

2 In eloquently written 6 chapters, the book discusses race relations and politics in Sudan starting from the 1950s till the separation in 2011. Using gender and intersectional perspectives, Ali examines the discourses and practices of the Sudanese opposition in exile. The author carefully analyses the interplay between gender and race, and to a lesser extent social class and religion, as tenants shaping Sudanese identity and power 
relations. Through a historical perspective, Ali delves into the contemporary dynamics of women's participation, discussions around women's human rights, nationalism and gender equality in Sudan and in exile. She examines these questions looking closely at the opposition movements organised under the umbrella of the National Democratic Alliance (NDA) in exile in the 1990s and early 2000s. She skillfully places these debates in a wider historical perspective of Sudanese politics which are developed in chapter 3 , sketching out the interplay of colonialism, nationalism and Islamism and the way they have resulted in socioeconomic and political exclusion and resistance.

One of the main contributions of the book is its longitudinal research, and Nada Ali's personal involvement in the opposition movement and exile politics since mid-1990s and her particular commitment to feminist coalition building among different Sudanese women's groups. In the introductory chapter, she discusses her positionality and shows how her political choices influenced her research. She was also a strong proponent of the New Sudan vision, which she saw, as many at that time, as an emancipatory project that was concerned with racial/cultural and regional difference. This reflexive account about her positionality adds depth to her analysis and shows how her personal stands are intertwined with her research subjects. Based on multisited ethnographic, document review and discourse analysis research in Egypt, Kenya, and Eritrea between 1998 and 1999, and on research of activisms in Sudan, South Sudan, and in the diaspora between 2010 and 2014, using feminist and intersectional analysis, the book shows how gender and race play key role in shaping contemporary political debates in Sudan and South Sudan. More importantly, these issues are also central to the ways women's movements have been organising in the two countries since the mid 1950s. They are also, as Ali demonstrates, the limits to the transnational coalition building centered on women's issues in the two countries and in the diasporas.

4 The book is organized into 6 chapters followed by a conclusion and an epilogue. The introduction sets the scene and effectively introduces the key focus of the book, while providing an elegant grounding of the concepts in academic, especially feminist, writings on nationalism, gender and intersectionality, and nation-building projects. The book is firmly anchored in feminist theorisations of nationalism, with particular references to Nira Yuval-Davis's work which clearly influenced Ali's thinking, coalition building and the role of women's movements in nation building. It provides rich interview material and in-depth analysis of documents and speeches, as well as author's encounters with the different women's groups and activists in exile. Ali provides detailed feminist and intersectional analysis of Sudanese women's activisms throughout the $20^{\text {th }}$ century, with a careful examination of the activities of exiled Sudanese and South Sudanese women in the 1990s and 2000s. Chapter 4 examines in depth the gendered discourses and, and to a lesser extent, practices of the Sudanese opposition in exile. Chapter 5, on the other hand, focuses its analysis on the ways gender and race were intertwined in the emancipatory project of New Sudan. Ali shows also how this vision turned later into further oppression and marginalisation. Chapter 6 provides some insights into how women's movements in Sudan and in South Sudan, as well as in the diasporas in Egypt and in Kenya, tried to resist further marginalisation and exclusion, yet their actions were not always successful. The coalition building proved difficult based on the deep racist and classist divisions. 
5 The subject of the book is thematic given the current political changes in Sudan and the role women played in the uprising in 2019. The book clearly shows that despite difficult political situation and the constraints imposed on women in Sudan under the sharia law since the 1980s, with more drastic regulations pertaining to personal freedoms linked to the Public Order act of 1999 , women have also played an active role in Sudanese politics and strived to carve out a place for their activism. It is a compelling, well-written and insightful account of the politics of gender and race relations that underlie transnational coalition building among women's groups. The book is a valuable contribution to the history of women's movement in Sudan and in South Sudan, and the role of women in the nation building projects in the two countries.

6 Some of the shortcomings of the book are also acknowledged by the author. The vast of the research is focused among Northern Sudanese women activists, and the South Sudanese and other regional women's groups are covered to a much lesser extent. The historical take on women's activism in South Sudan, before the separation but also after, is tackled in a rather superficial way. Much more research is needed to show the historical diversities and regional particularities to women's organising and women's participation in nation-building processes in Sudan in general, and in South Sudan in particular. Nonetheless, the book offers important insights into the gendered politics of social movements, of nationalism, and deeply imbedded patriarchy in Sudan. While focused on particular case study, the book draws wider implications for understanding these phenomena worldwide.

7 The intersectional analysis with a particular focus on race is key to understand how gender and race are essential to make sense of social movements and social transformations. Social class and religion are important parameters, yet the book does not focus its analysis on them. Written by an engaged feminist academic, this book is a valuable read for academics, politicians and foremost activists committed to build a new Sudan, and more widely, inclusive and equal citizenship projects worldwide.

\section{AUTHORS}

\section{KATARZYNA GRABSKA}

Peace Research Institute, Oslo, Norway; Institute of Ethnology, Neuchâtel University, Switzerland 